ఠ

\title{
Biodistribution of newly synthesized PHEA-based polymer-coated SPION in Sprague Dawley rats as magnetic resonance contrast agent [Corrigendum]
}

Park J, Cho W, Park HJ, et al. Int J Nanomed. 2013;8(1):

4077-4089.

On page 4077, please note that Sun-Hang Cho's affiliation was given as " ${ }^{5}$ Korea United Pharm Inc, Seoul, Republic of Korea". The correct affiliation for Sun-Hang Cho is

"'Biomaterials Laboratory, Korea Research Institutes of Chemical Technology, Daejeon, Republic of Korea".

The International Journal of Nanomedicine is an international, peerreviewed journal focusing on the application of nanotechnology in diagnostics, therapeutics, and drug delivery systems throughout the biomedical field. This journal is indexed on PubMed Central, MedLine, CAS, SciSearch ${ }^{\circledR}$, Current Contents ${ }^{\circledR} /$ Clinical Medicine,
Journal Citation Reports/Science Edition, EMBase, Scopus and the Elsevier Bibliographic databases. The manuscript management system is completely online and includes a very quick and fair peer-review system, which is all easy to use. Visit http://www.dovepress.com/ testimonials.php to read real quotes from published authors. submit your manuscript | www.dovepress.com

Dovepress

http://dx.doi.org/10.2147/IJN.S57| 25 